\title{
Sweet potato feathery mottle virus and Sweet potato virus $C$ from East Timorese and Australian Sweetpotato: Biological and Molecular Properties, and Biosecurity Implications
}

Solomon Maina, School of Agriculture and Environment and University of Western Australia (UWA) Institute of Agriculture, Faculty of Science, UWA, Crawley, WA 6009, Australia; and Cooperative Research Centre for Plant Biosecurity, Canberra, ACT 2617, Australia; Martin J. Barbetti, School of Agriculture and Environment and UWA Institute of Agriculture, Faculty of Science, UWA; and Cooperative Research Center for Plant Biosecurity, Canberra, Australia; Owain R. Edwards, Commonwealth Scientific and Industrial Research Organisation Land and Water, Floreat Park, WA 6014, Australia; and Cooperative Research Centre for Plant Biosecurity, Canberra; Luis de Almeida, Seeds of Life Project, Ministry Agriculture and Fisheries, Dili, East Timor; Abel Ximenes, DNQB-Plant Quarantine, International Airport Nicolau Lobato Comoro, Dili, East Timor; and Roger A. C. Jones, ${ }^{\dagger}$ Department of Agriculture and Food Western Australia, South Perth, WA 6151, Australia; UWA Institute of Agriculture, Faculty of Science, UWA; and Cooperative Research Centre for Plant Biosecurity, Canberra

\begin{abstract}
Sweet potato feathery mottle virus (SPFMV) and Sweet potato virus $C$ (SPVC) isolates from sweetpotato were studied to examine genetic connectivity between viruses from Australia and Southeast Asia. East Timorese samples from sweetpotato were sent to Australia on FTA cards. Shoot and tuberous root samples were collected in Australia and planted in the glasshouse, and scions were graft inoculated to Ipomoea setosa plants. Symptoms in infected sweetpotato and I. setosa plants were recorded. RNA extracts from FTA cards and I. setosa leaf samples were subjected to high-throughput sequencing (HTS). Complete genomic sequences (CS) of SPFMV and SPVC (11 each) were obtained by HTS, and coat protein (CP) genes from them were compared with others from GenBank. SPFMV sequences clustered into two major phylogroups $(\mathrm{A}$ and $\mathrm{B}=\mathrm{RC}$ ) and two minor phylogroups (EA[I] and $\mathrm{O}[\mathrm{II}]$ ) within A; East Timorese sequences were in $\mathrm{EA}(\mathrm{I})$ and $\mathrm{O}(\mathrm{II})$, whereas Australian sequences were in $\mathrm{O}(\mathrm{II})$ and $\mathrm{B}(\mathrm{RC})$. With SPVC, CP trees provided sufficient diversity to distinguish major phylogroups A and B and six minor phylogroups within A (I to VI); East Timorese sequences were in minor phylogroup I, whereas Australian

sequences were in minor phylogroups II and VI and in major phylogroup B. With SPFMV, Aus13B grouped with East Timorese sequence TM64B within minor phylogroup $\mathrm{O}$, giving nucleotide sequence identities of 97.4\% (CS) and 98.3\% (CP). However, the closest match with an Australian sequence was the $97.6 \%$ (CS) and $98.7 \%$ (CP) nucleotide identity between Aus13B and an Argentinian sequence. With SPVC, closest nucleotide identity matches between Australian and East Timorese sequences were $94.1 \%$ with Aus6a and TM68A (CS) and 96.3\% with Aus55-4C and TM64A (CP); however neither pair member belonged to the same minor phylogroup. Also, the closest Australian match was $99.1 \%$ (CP) nucleotide identity between Aus4C and New Zealand isolate NZ4-4. These first complete genome sequences of SPFMV and SPVC from sweetpotato plantings in the Australian continent and neighboring Southeast Asia suggest at least two (SPFMV) and three (SPVC) separate introductions to Australia since agriculture commenced more than two centuries ago. These findings have major implications for both healthy stock programs and biosecurity management in relation to pathogen entry into Australia and elsewhere.
\end{abstract}

Sweetpotato (Ipomoea batatas; family Convolvulaceae) is a robust annual crop producing edible tuberous roots that grow well in poor soils and withstand harsh climatic conditions, and is one of the world's most important staple food crops (FAOSTAT 2015; Kays et al. 2005). Its center of domestication is Central America and the Andean region of South America but it is now grown as a crop in all tropical or subtropical regions of the developed and developing world. It is an important food crop in Australia, where it is widely grown in the north of the continent, and in Southeast Asia and Oceania, including three neighboring countries to Australia's north: East Timor, Indonesia, and Papua New Guinea (PNG). Sweetpotato production is constrained globally by diseases caused by RNA and DNA viruses. Sweet potato feathery motile virus (SPFMV; genus Potyvirus, family Potyviridae) is the most important and widespread

${ }^{\dagger}$ Corresponding author: Roger A .C. Jones;

E-mail: roger.jones@agric.wa.gov.au

The Cooperative Research Centre for Plant Biosecurity (PBCRC61056) and the University of Western Australia provided a Scholarship for International Research Fees. Both organizations and the Commonwealth Scientific and Industrial Research Organisation provided operating funds.

*The $\boldsymbol{e}$-Xtra logo stands for "electronic extra" and indicates that one supplementary figure and two supplementary tables are published online.

Accepted for publication 7 October 2017.

C 2018 The American Phytopathological Society sweetpotato virus (Clark et al. 2012; Karyeija et al. 1998; Kashif et al. 2012; Moyer and Salazar 1989; Rännäli et al. 2009 ; Tairo et al. 2005, 2006a). SPFMV consists of three recognized phylogroups: East African (EA), Ordinary (O), and Russet Crack (RC) (Kreuze et al. 2000; Moyer et al.1980; Tairo et al. 2005). Sweet potato virus C (SPVC; genus Potyvirus, family Potyviridae), formerly called SPFMV strain C, also occurs worldwide (Clark et al. 2012; Tairo et al. 2005). SPFMV and SPVC often occur together in the same sweetpotato plants. They are both spread via aphids, which transmit them nonpersistently, and when planting cuttings or tuberous roots (Clark et al. 2012; Loebenstein et al. 2009).

SPVC and SPFMV strains $\mathrm{O}$ and RC infect sweetpotato in North and South America, Europe, Australasia, Oceania, Africa, and Asia (Brunt 1987; CABI/EPPO 2003; Clark et al. 2012; Colinet et al. 1998; EPPO 2014; Fletcher et al. 2000; Gibb and Padovan 1993; Gibbs and Mackenzie 1997; Ha et al. 2008; IsHak et al. 2003; Jones and Dwyer 2007; Kreuze et al. 2000; Pearson et al. 2002; Rännäli et al. 2009; Ryu et al. 1998; Salazar and Fuentes 2000; Tairo et al. 2005; 2006a; Untiveros et al. 2008; Valverde et al. 2007). SPFMV strain EA was first found in sweetpotato in East Africa (Kreuze et al. 2000; Mukasa et al. 2003; Tairo et al. 2005) but was detected subsequently elsewhere (e.g., in Peru in South America and Vietnam in Southeast Asia) (Ha et al. 2008; Untiveros et al. 2008). SPVC and SPFMV strains $\mathrm{O}$ and RC both infect sweetpotato in Australia (Jones and Dwyer 2007; Tairo et al. 2005, 2006a). In neighboring countries to Australia's north, SPFMV occurs in sweetpotato in Indonesia and PNG (Atkey and Brunt 1987; Coleman et al. 2009; Prain et al. 1998; Purnomo 2003) but there are no reports about which of its strains is present or whether SPVC occurs, and no information whatsoever about either virus from East Timor. 
Agriculture commenced more than 8,000 years ago in Southeast Asia (Hutterer 1983) and about 7,000 years ago on the island of New Guinea (Denham et al. 2004) but, on the Australian continent it, only started after colonization by Europeans in 1788 and, in remote regions, as recently as the 1960 s. In consequence, many viruses and virulent virus strains that cause damaging crop diseases elsewhere in the world are absent from or only recently arrived in Australia. Most virus spread from other countries to Australia seems due to human activities involving trade in plants and plant products, mostly involving unknowingly infected seed or vegetative propagules (Gibbs et al. 2008; Jones 2009). However, from November to April, annually strong northwesterly monsoonal winds bringing cloud and heavy rainfall blow from East Timor and Indonesia across the sea toward northern Australia. These monsoonal winds could bring viruliferous insect vectors that introduce viruses (Eagles et al. 2013; Maina et al. 2017a,b). Evidence that this may have already occurred was provided when isolates of Zucchini yellow mosaic virus (ZYMV; genus Potyvirus, family Potyviridae) were sequenced from all around the Australian continent. Isolates from the Ord River Irrigation Area near Kununurra in the East Kimberley region of northwest Australia matched ones from East Timor, Singapore, and Vietnam. By contrast, none of the isolates collected from Broome in the West Kimberley, Darwin in the Northern Territory (which is adjacent to the East Kimberley), or any other Australian locations belonged to this phylogroup; thus, only those from Kununurra demonstrated "genetic connectivity" (a biosecurity term used to describe matching nucleic acid sequence identities among samples derived from different countries) (Coutts et al. 2011; Maina et al. 2017a). The ZYMV phylogroup concerned has only been found in Reunion Island near Africa, Southeast Asia, and this remote region of northwest Australia. Because both SPFMV and SPVC resemble ZYMV in being potyviruses transmitted nonpersistently by aphids (Clark et al. 2012; Loebenstein et al. 2009), one way they could have reached northern Australia is via viruliferous aphid vectors blown by monsoonal wind currents from a nearby Southeast Asian country such as East Timor. However, an alternative explanation is that infected cucurbit seed from a Southeast Asian country could have introduced the ZYMV, while infected tuberous roots from there could have introduced the SPFMV and SPVC.

This article forms part of a series arising from a plant biosecurity project testing the hypothesis that "important plant viral pathogens of economically important crops are arriving in tropical northern
Australia by crossing the sea separating it from its northern Australian neighbors" (Maina et al. 2016a,b,c,d,e,f, 2017a,b,c,d,e,f). Although SPFMV and SPVC isolates from Australia have been sequenced (Jones and Dwyer 2007; Tairo et al. 2005, 2006a), no complete Australian genomic sequences are available, and neither are any from neighboring countries to Australia's north. In this study, in addition to describing symptoms that developed in sweetpotato and graft-inoculated I. setosa plants, we report obtaining 22 new complete genome sequences of SPFMV and SPVC isolates (11 each) from sweetpotato samples collected in two and three different locations in East Timor and Australia, respectively. These are not only the first complete SPFMV and SPVC genomes from both countries but also the first ones from Southeast Asia and Australasia. They were used to investigate whether any genetic connectivity occurs (i) between the Australian SPFMV and SPVC populations and those of its northern neighbors and (ii) between coat protein $(\mathrm{CP})$ genes from the new genomes and SPFMV and SPVC $\mathrm{CP}$ sequences already available in GenBank.

\section{Materials and Methods}

Sample collection. In May 2015, 15 leaf samples were collected from sweetpotato plants with virus-like symptoms growing in smallholder farms in the Alieu, Dili, Loes, and Maubisse districts of East Timor (Fig. 1A; Table 1); details of foliage symptoms were unavailable for the plants sampled. Sap from each potentially symptomatic leaf sample was blotted onto FTA Classic Cards (GE Healthcare), as described by Ndunguru et al. (2005). The cards were air dried for $10 \mathrm{~min}$ at room temperature before shipment to Perth in southwest Australia. In total, 16 samples were collected at Broome, West Kimberley region, northwest Australia in early October 2015. They consisted of 14 sweetpotato shoots and two tuberous roots, each from a different plant, from commercial farms, educational institutions, and local back gardens. Any symptoms present in sweetpotato foliage were recorded before sampling. The shoots and tuberous root samples were transported to Perth in cooler boxes. In addition, plants grown from two sweetpotato samples of 'Jewel' from Broome and two others apparently of 'Kestle' from Canberra collected in 2004 and 2005, respectively (Jones and Dwyer 2007; Tairo et al. 2006a), were resampled. These source plants had been maintained until 2015 by replanting tuberous roots annually. Sample 55-6 from Broome was previously found to contain SPFMV-RC and Sweet potato virus 2 (SPV2; genus Potyvirus, family Potyviridae) (Jones and Dwyer 2007), whereas sample $2 \mathrm{a}$ from Canberra was found infected

A

B
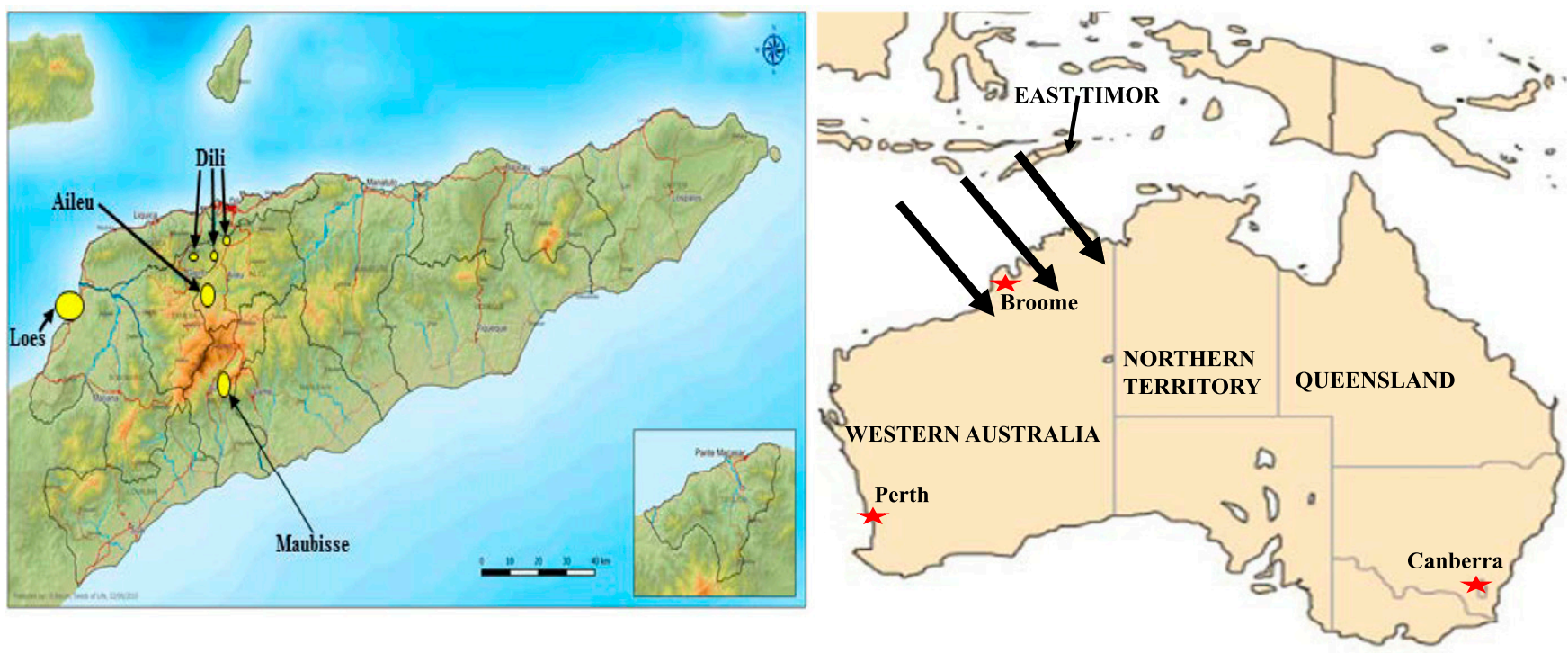

Fig. 1. Map showing locations in East Timor and the Australian mainland where sweetpotato leaf samples infected with Sweet potato virus $C$ and Sweet potato feathery mottle virus were collected from sweetpotato plantings. A, Sampling locations in East Timor. The inset shows a small enclave that is also part of East Timor. B, Sampling locations in Australia and the position of East Timor in relation to Australia. The sampling locations Fremantle, Subiaco, and Wellard are all suburbs of Perth. Arrows show annual November-to-April prevailing monsoonal wind direction. 
with SPFMV-RC, SPV2, and Sweet potato chlorotic fleck virus (SPCFV; genus Carlavirus, family Betaflexiviridae) (Jones and Dwyer 2007; Tairo et al. 2006a). Additional new sweetpotato samples from the Perth region consisted of (i) two tuberous roots each from markets in Fremantle and Subiaco, Perth, and (ii) three shoots: two from plots in South Perth and one from a garden in Wellard (Tables 1 and 2). All samples were planted in potting mix and in air-conditioned, insect-proof glasshouses maintained at approximately $23^{\circ} \mathrm{C}$. A single scion from each of 18 sweetpotato plants was side grafted to a healthy plant of I. setosa. The foliage of each of the sweetpotato and graft-inoculated I. setosa plants was recorded weekly for virus symptoms for up to 2 months. Also, because cultivar names were mostly lacking, distinguishing morphological and other characteristics were recorded for each sweetpotato plant, and the tuberous roots they produced, to distinguish the different types present. For this, tuberous root (shape, skin, and flesh color) and foliage (leaf shape, and leaf, petiole, and stem color) characteristics were used as primary and secondary descriptors, respectively.

RNA extraction and reverse-transcription polymerase chain reaction. The 15 East Timorese samples blotted onto FTA cards were sampled by punching 20 discs (approximately $2 \mathrm{~mm}$ in diameter) from each of them. Total RNA was extracted from these 20 discs and from $18 \mathrm{I}$. setosa leaf samples using a ZR Plant RNA MiniPrep kit (Zymo Research) according to the manufacturer's instructions. Crude RNA was treated with RNase-free DNase (Invitrogen) and quality control was performed as described previously (Maina et al. 2016a,b,c,d,e, f, 2017a,b,c,d,e,f; Guerret et al. 2017). Reverse-transcription polymerase chain reaction (RT-PCR) was performed using GoTaq Green master mix (Promega Corp.) and generic Potyvirus LegPotyF and LegPotyR primers, as described by Webster (2008). Only 14 of the 25 Australian and 5 of the 15 East Timorese samples showed evidence of potyvirus presence.

Library preparation. Total RNA extracts from all of the 15 East Timorese samples, the 14 Australian samples that showed evidence of potyvirus presence, and 4 other Australian samples were used. Libraries were prepared from 0.1 to $1 \mu \mathrm{g}$ of total RNA using the
TruSeq-stranded Total RNA Sample Preparation kit with Ribozero Plant (Illumina). This involved subjecting the total RNA to depletion of ribosomal RNA (rRNA) using rRNA removal mix-Plant, as described previously (Maina et al. 2016a,b,c,d,e,f, 2017a,b,c,d,e,f). However, because of the low quality of RNA, the procedure was slightly modified by increasing the volume of Agencourt AMPure XP beads (Beckman Coulter) by $20 \%$ in every clean-up and omitting the RNA fragmentation step with RNA from FTA cards. Extracts were primed with random hexamers, and first-strand cDNA synthesis was done using a mixture of Superscript II and Actinomycin D to allow RNA-dependent synthesis and inhibit DNA-dependent synthesis, respectively. Second-strand cDNA synthesis was done using dUTP instead of dTTP to create stranded cDNA. The libraries were then adenylated at the $3^{\prime}$ end. Set A and B adaptors containing the identifier sequences and flow-cell-binding sequences were ligated to both ends. The cDNA fragment was enriched by 15 cycles and quality control was as described by Maina et al. (2016a,b,c,d,e,f, 2017a,b,c,d,e,f).

High-throughput sequencing. Ten nanomolar library pools were prepared by mixing the libraries to achieve an equal molar concentration of each. To establish the most cost-effective coverage, two sequencing runs were performed. The first run involved sequencing a pool of 12 denatured libraries in a MiSeq using a $2 \times 251$ v2 kit to generate paired-end reads (Illumina), and a $1 \%$ PhiX v3 spike was included. The second run involved sending ready-stranded libraries to Macrogen Inc., where they were subjected to HiSeq 2500 sequencing using a TruSeq rapid SBS kit v4 (Illumina) with 151 cycles to generate paired-end reads in a multiplex of 24 samples per lane.

Sequence analysis. After sequencing, RNA-seq reads were subjected to quality control using CLC Genomics Workbench 6.5 (CLCGW; CLC Bio, Qiagen) followed by de novo assembly, as described previously (Guerret et al. 2017; Kehoe et al. 2014; Maina et al. 2016a,b,c,d,e,f, 2017a,b,c,d,e,f). All the contigs were subjected to the BLAST search tool from the National Center for Biotechnology Information using CLCGW and, subsequently, to PASC sequence comparisons (Altschul et al. 1990; Bao et al. 2014). The

Table 1. Details of the 18 virus-infected sweetpotato samples that provided complete genome sequences and the 22 Sweet potato feathery mottle virus (SPFMV) and Sweet potato virus $C$ (SPVC) genomes sequenced ${ }^{\mathrm{a}}$

\begin{tabular}{|c|c|c|c|c|c|c|}
\hline Samples & Geographic origin & Year of sampling & Sample origin or supplier & Isolate & Viruses sequenced & Accession number \\
\hline $1 \mathrm{a}^{\mathrm{b}}$ & Canberra, ACT & 2005 & Roger Jones & Aus1A & SPVC & MF572057 \\
\hline $1 \mathrm{a}$ & Canberra, ACT & 2005 & Roger Jones & Aus2A & SPVC & MF572058 \\
\hline $2 a^{b}$ & Canberra, ACT & 2005 & Jones and Dwyer 2007 & Aus2D & SPFMV-B $(R C)^{\mathrm{c}}$ & MF572051 \\
\hline 53 & Broome, WA, Australia & 2004 & Roger Jones & Aus3A & SPVC & MF572059 \\
\hline 53 & Broome, WA, Australia & 2004 & Roger Jones & Aus3D & SPFMV-B(RC) & MF572052 \\
\hline $55-6$ & Broome, WA, Australia & 2004 & Jones and Dwyer 2007 & Aus4D & SPFMV-B $(R C)^{c}$ & MF572047 \\
\hline $1 \mathrm{Br}-\mathrm{A}$ & Broome, WA, Australia & 2015 & This study & Aus5A & SPVC & MF572060 \\
\hline $1 \mathrm{Br}-\mathrm{B}$ & Broome, WA, Australia & 2015 & This study & Aus6A & SPVC & MF572061 \\
\hline $10 \mathrm{Br}-\mathrm{A}$ & Broome, WA, Australia & 2015 & This study & Aus7D & SPFMV-B(RC) & MF572046 \\
\hline $10 \mathrm{Br}-\mathrm{B}$ & Broome, WA, Australia & 2015 & This study & Aus8A & SPVC & MF572062 \\
\hline $62 \mathrm{Br}^{\mathrm{b}}$ & Broome, WA, Australia & 2015 & This study & Aus9D & SPFMV-B(RC) & MF572054 \\
\hline $\mathrm{Sb}-\mathrm{RT}^{\mathrm{b}}$ & Subiaco, WA, Australia & 2015 & This study & Aus10A & SPVC & MF572063 \\
\hline SP-1 & South Perth, WA, Australia & 2015 & This study & Aus11D & SPFMV-B(RC) & MF572048 \\
\hline $\mathrm{F}-1^{\mathrm{b}}$ & Fremantle, WA, Australia & 2015 & This study & Aus13B & SPFMV-A-O(II) & MF572050 \\
\hline Wel-1 & Wellard, WA, Australia & 2015 & Brenda Coutts & Aus12D & SPFMV-B(RC) $)^{d}$ & MF572049 \\
\hline TM33 & Dili, East Timor & 2015 & This study & TM33A & SPVC & MF572064 \\
\hline TM33 & Dili, East Timor & 2015 & This study & TM33C & SPFMV-A-EA(I) & MF572055 \\
\hline TM37 & Dili, East Timor & 2015 & This study & TM37 & $-\mathrm{c}$ & $-\mathrm{c}$ \\
\hline TM64 & Aileu, East Timor & 2015 & This study & TM64A & SPVC & MF572065 \\
\hline TM64 & Aileu, East Timor & 2015 & This study & TM64B & SPFMV-A-O(II) & MF572053 \\
\hline TM66 & Aileu, East Timor & 2015 & This study & TM66A & SPVC $^{c}$ & MF572066 \\
\hline TM66 & Aileu, East Timor & 2015 & This study & TM66B & SPFMV-A-O(II) & MF572056 \\
\hline TM68 & Aileu, East Timor & 2015 & This study & TM68A & SPVC & MF572067 \\
\hline
\end{tabular}

a Partial SPFMV or SPVC sequences were obtained from three additional samples: 59Br from Broome with SPFMV-RC, SP-II from South Perth with SPFMV-O, and TM37 from Dili, East Timor with both SPFMV-O and SPFMV-EA. ACT = Australian Capital Territory and WA $=$ Western Australia; $\mathrm{RC}=$ russet crack, $\mathrm{O}=$ ordinary, and EA = East African

${ }^{\mathrm{b}}$ Sample derived from tuberous root obtained directly from the field or purchased indirectly from a market. All other samples came from shoots collected in the field.

${ }^{c}$ Other viruses were found in and sequenced separately from these samples.

d A partial sequence of Sweet potato pakakuy virus strain B was also obtained from sample Wel-1. 
contigs were sorted by length and examined individually. All contigs with plant virus matches were used for further analysis. In addition, trimmed reads from CLCGW were imported into Geneious 8.1.7 (Biomatters Ltd.) (Kearse et al. 2012) before mapping to a reference sequence from GenBank, as described by Kehoe et al. (2014). Consensus sequence integrity was observed and its full length used with the contig of interest from CLCGW in Geneious by alignment with MAFFT (Katoh et al. 2002) to create a final sequence. SPFMV and SPVC coding regions were improved by aligning nucleotide sequences to the aligned deduced amino acid sequences using MUSCLE (available in Geneious). Open reading frames were predicted and annotations made using Geneious. Finalized sequences were designated as complete coding sequences based on comparison with the reference sequences used in the mapping process. Where sequences differed in length, this was because some nucleotides in the $5^{\prime}$ or $3^{\prime}$ untranslated regions were missing, although their complete polyprotein coding regions were always intact. Nucleotide percentage identity differences were calculated for the complete genomes using the pairwise comparison function in Geneious with the number of differences model. Final sequences were deposited in GenBank under the accession numbers MF572046 to MF572067.

Phylogenetics. Using ClustalW in MEGA 7.0.14 (Kumar et al. 2016), the coding regions of the 22 new complete SPFMV and SPVC genome sequences were aligned with those of 13 SPFMV or 10 SPVC other complete, nonredundant, genome sequences, respectively, from other parts of the world retrieved from GenBank. Details of all of the complete SPFMV and SPVC sequences from GenBank, including which phylogroups they belong to, where this is recorded, are provided in Supplementary Table S1. Further alignments were obtained using MAFFT in Geneious (Katoh et al. 2002). Phylogenetic analysis compared (i) the coding regions of the 8 and 3 new complete SPFMV genome sequences from Australia and East Timor, respectively, with the 13 other complete SPFMV genomes; (ii) the extracted CP genes from the 11 new SPFMV genome sequences

Table 2. Details of the 18 sweet potato samples that provided complete virus genomes: Foliage symptoms in sweetpotato and Ipomoea setosa, distinguishing characteristics in progeny plants and tuberous roots, and viruses sequenced

\begin{tabular}{|c|c|c|c|c|c|c|c|c|c|c|c|}
\hline \multirow[b]{2}{*}{ Sample } & \multicolumn{3}{|c|}{ Foliage symptoms ${ }^{\mathbf{a}}$} & \multicolumn{2}{|c|}{ Morphology and color descriptors } & \multicolumn{6}{|c|}{ Virus detected $^{\mathbf{b}}$} \\
\hline & Field & Glasshouse & I. setosa & Foliage $^{c}$ & Root $^{d}$ & SPFMV & SPVC & SPCFV & SPVG & SPV2 & SPPV-B \\
\hline $1 \mathrm{a}^{\mathrm{e}}$ & NA & $\mathrm{M}, \mathrm{VC}$ & $\mathrm{C}, \mathrm{M}, \mathrm{LM}, \mathrm{VC}$ & $\begin{array}{l}\text { PoTriLoL, PuTiL ReP, } \\
\text { ReSt }\end{array}$ & El, WhF, WhSk & + & + & - & - & - & - \\
\hline $2 \mathrm{a}^{\mathrm{e}}$ & NA & CLP & $\mathrm{C}, \mathrm{LM}, \mathrm{VC}$ & $\begin{array}{l}\text { PoTriLoL, PuL' ReP, } \\
\text { ReSt }\end{array}$ & $\begin{array}{l}\text { El, GoBrSk, } \\
\text { WhF }\end{array}$ & - & + & $\begin{array}{l}\text { + Jones and } \\
\text { Dwyer } \\
2007 ; \\
\text { Maina } \\
\text { et al. } \\
\text { 2016b }\end{array}$ & - & $\begin{array}{l}\text { + Maina } \\
\text { et al. } \\
2016 \mathrm{c} \text {; } \\
\text { Tairo } \\
\text { et al. } \\
\text { 2006a }\end{array}$ & - \\
\hline 53 & $\mathrm{C}$ & LLC, CS & $\mathrm{LM}, \mathrm{M}, \mathrm{VC}$ & GrP, GrSt, HsL, PuL & LnEl, OrF, OrSk & + & + & - & - & - & - \\
\hline $55-6$ & $\mathrm{CB}$ & LLC, C & $\mathrm{C}, \mathrm{LM}, \mathrm{VC}$ & GrP, GrSt, HsL, PuL & LnEl, OrF, OrSk & + & - & - & - & $\begin{array}{c}\text { + Tairo } \\
\text { et al. } \\
\text { 2006a }\end{array}$ & - \\
\hline $1 \mathrm{Br}-\mathrm{A}$ & $\begin{array}{l}\text { CB, } \\
\text { PuR }\end{array}$ & $\mathrm{CB}, \mathrm{PuRS}$ & $\mathrm{C}, \mathrm{M}, \mathrm{LM}$ & $\begin{array}{l}\text { GrP, GrSt, PoTriLoL, } \\
\text { PuTiGrL }\end{array}$ & El, GoBrSk, OrF & - & + & - & - & - & - \\
\hline $1 \mathrm{Br}-\mathrm{B}$ & $\mathrm{Cr}$ & CB, PuR & $\mathrm{C}, \mathrm{LM}, \mathrm{M}$ & $\begin{array}{l}\text { GrP, GrSt, PoTriLoL, } \\
\text { PuTiGrL }\end{array}$ & El, GoBrSk,OrF & - & + & - & - & - & - \\
\hline $10 \mathrm{Br}-\mathrm{A}$ & $\mathrm{Cr}$ & $\mathrm{CB}$ & $\mathrm{M}, \mathrm{LDC}, \mathrm{VC}$ & $\begin{array}{l}\text { GrL, HsL, PuTiP, } \\
\text { PuTiSt }\end{array}$ & El, GoBrSk, OrF & + & - & - & - & - & - \\
\hline 10Br-B & $\mathrm{Cr}$ & $\mathrm{CB}, \mathrm{M}, \mathrm{R}$ & $\mathrm{M}, \mathrm{LM}, \mathrm{VC}$ & $\begin{array}{l}\text { GrL, HsPoL, PuTiP, } \\
\text { PuTiSt }\end{array}$ & Ov, ReSk, WCF & - & + & - & - & - & - \\
\hline $62-\mathrm{Br}^{\mathrm{e}}$ & NA & $\mathrm{CB}$ & $\mathrm{C}, \mathrm{M}, \mathrm{LM}$ & $\begin{array}{l}\text { GrL, HsL, PuTiP, } \\
\text { PuTiSt }\end{array}$ & $\mathrm{El}, \mathrm{GoBrSk}, \mathrm{OrF}$ & - & + & - & - & - & - \\
\hline $\mathrm{Sb}-\mathrm{RT}^{\mathrm{e}}$ & NA & $\mathrm{CB}$ & M, LM, VB & $\begin{array}{l}\text { HsL, PuL, PuTiP, } \\
\text { PuTiSt }\end{array}$ & El, PuSk, WCF & - & + & - & - & - & - \\
\hline SP-1 & NR & SS & SS & HsPoL, ReL, ReP, RSt & El, PuSk, WCF & + & - & - & - & - & - \\
\hline $\mathrm{F}-1^{\mathrm{e}}$ & NA & CS & $\mathrm{C}, \mathrm{M}, \mathrm{VC}$ & $\begin{array}{l}\text { GrP, GrSt, HsL, } \\
\text { PuL }\end{array}$ & El, PuSk, WCF & + & - & - & - & - & - \\
\hline Wel-1 & NR & CS, PuR & $\mathrm{C}, \mathrm{LM}$ & $\begin{array}{l}\text { GrSt, HsL, PuTiP, } \\
\text { PuL }\end{array}$ & $\begin{array}{l}\text { OvOb, } \\
\text { PuSk, CrF }\end{array}$ & + & - & - & - & - & + \\
\hline TM33 & NR & NA & NA & NA & NA & - & + & - & - & - & - \\
\hline TM37 & NR & NA & NA & NA & NA & - & - & $\begin{array}{l}\text { + Maina } \\
\text { et al. } \\
2016 \mathrm{~b}\end{array}$ & & $\begin{array}{l}\text { + Maina } \\
\text { et al. } \\
2016 \mathrm{c}\end{array}$ & - \\
\hline TM64 & NR & NA & NA & NA & NA & + & + & - & - & - & - \\
\hline TM66 & NR & NA & NA & NA & NA & + & + & - & $\begin{array}{l}\text { + Maina } \\
\text { et al. } \\
\text { 2016a }\end{array}$ & - & - \\
\hline TM68 & NR & NA & NA & NA & NA & - & + & - & - & - & - \\
\hline
\end{tabular}

a Foliage symptoms: $\mathrm{C}=$ chlorosis, $\mathrm{CB}=$ chlorotic blotches, $\mathrm{Cr}=$ Crinkling, $\mathrm{CLP}=$ chlorotic line patterns, $\mathrm{CS}=$ chlorotic spots, $\mathrm{LM}=$ leaf malformation, $\mathrm{LLC}=$ lower leaf chlorosis, $\mathrm{M}=$ mosaic, $\mathrm{LDC}=$ leaf downcurling, $\mathrm{NA}=$ not applicable, $\mathrm{NR}=$ not recorded, $\mathrm{PuR}=$ purple rings, $\mathrm{PuRS}=$ purple ringspots, $\mathrm{R}=$ rugosity, $\mathrm{SS}=$ symptomless infection, $\mathrm{VB}=$ vein banding, and $\mathrm{VC}=$ vein clearing

${ }^{\mathrm{b}}$ Sweet potato feathery mottle virus (SPFMV), Sweet potato virus C (SPVC), Sweet potato chlorotic fleck virus (SPCFV), Sweet potato virus G (SPVG), Sweet potato virus 2 (SPV2), and Sweet potato pakakuy virus strain B (SPPV-B, partial sequence); + indicates virus present and - indicates virus negative.

${ }^{c}$ Foliage descriptors: $\mathrm{GrP}=$ green petioles, $\mathrm{GrL}=$ green leaves, $\mathrm{GrSt}=$ green stems, $\mathrm{HsL}=$ heart-shaped leaves, $\mathrm{HsPoL}=$ heart-shaped pointed leaves, $\mathrm{NA}=$ not applicable, $\mathrm{Pol}=$ pointed leaves, $\mathrm{PoTriLoL}=$ pointed trilobed leaves, $\mathrm{PuL}=$ purple leaves, $\mathrm{PuTiL}=$ purple-tinged leaves, $\mathrm{PuTiP}=$ purple-tinged petioles PuTiGrL $=$ purple-tinged green leaves, $\mathrm{PuTiSt}=$ purple-tinged stems, $\mathrm{ReL}=$ Red leaves, $\mathrm{ReP}=$ red petioles, and $\mathrm{ReSt}=$ red stems.

d Tuberous root descriptors: $\mathrm{CrF}=$ cream flesh, $\mathrm{El}=$ elongated shape, $\mathrm{GoBrSk}=$ golden-brown skin, $\mathrm{LnEl}=$ long elongated shape, $\mathrm{NA}=$ not applicable, $\mathrm{OrF}=$ orange flesh, $\mathrm{OrSk}=$ orange skin, $\mathrm{Ov}=$ oval shape, $\mathrm{OvOb}=$ oval oblong shape, $\mathrm{PuSk}=$ purple skin, $\mathrm{ReSk}=$ red skin, $\mathrm{WCF}=$ white-cream flesh, $\mathrm{WhSk}=$ white skin, and $\mathrm{WhF}=$ white flesh.

e Tuberous root sample. 
and four Australian isolates sequenced previously (AJ781775-Aus2, AJ781776-Aus5, AJ781777-Aus6, and AM050890-Aus142-ARC) with the other 34 complete, representative SPFMV CP sequences; (iii) the coding regions of the 7 and 4 new complete SPVC genome sequences from Australia and East Timor, respectively, with the 10 other complete SPVC genome sequences; and (iv) the extracted CP gene sequences from the 11 new SPVC genome sequences and 5 Australian SPVC genomes sequenced previously (AJ781778Aus4C, AJ781779-Aus5C, M050891-Aus142-AC, AM05089255-4C, and AM050893-Pink-2C) with the other 46 complete, representative SPVC CP sequences; both of these CP analyses excluded partial and highly similar sequences retrieved from GenBank. Evolutionary history was inferred by the maximumlikelihood method using the Tamura-Nei model, with bootstrap support values of 1,000. The Tamura-Nei model was selected after testing eight different models because it provided the best nucleotide substitution fit. The codon positions included were first + second + third + noncoding. All ambiguous positions were removed for each sequence pair, and SPFMV and SPVC trees were rooted with SPVC IL (X489166) and SPFMV-EA Piu 3 (FJ155666), respectively. Two within-virus species phylogroup classification systems were used. The first is based on distinguishing biological characteristics or the region of the world where each isolate originated. The second uses a neutral nomenclature system involving Latinized numerals that avoids potentially misleading names based on biology or geography (Jones and Kehoe 2016).

\section{Results}

Symptoms in sweetpotato and I. setosa plants. Of the 14 new shoot samples collected in the field in Broome in 2015, 10 were from asymptomatic sweetpotato plants. Leaf symptoms consisting of purple rings and chlorotic blotches (Fig. 2A) or crinkling were present in the four plants with symptoms (Table 2). The two shoot samples collected from the field in Broome in 2004 (53 and 55-6) originally came from plants exhibiting chlorotic blotch or chlorosis leaf symptoms. No plant symptoms were available for the three shoot samples from South Perth or Wellard. None of the two new tuberous root samples collected in the field in Broome or four from markets in Subiaco, Perth, or Fremantle exhibited russet crack symptoms. When all of the 25 shoot or tuberous root sweetpotato samples were planted in the glasshouse, 13 of the plants that grew from them developed leaf symptoms, which consisted of crinkling, blotches or line patterns, purple rings or ringspots, vein clearing, mosaic, rings, or chlorosis. Each symptomatic plants exhibited one to three of these different symptom types (Fig. 2B to E; Table 2).

Among the 25 grafted-inoculated I. setosa plants, 14 developed virus symptoms but 11 were asymptomatic. The foliage symptoms consisted of leaf vein clearing, vein banding, mosaic, malformation, downcurling, and chlorosis. Each symptomatic plant exhibited two to four of these different types of symptom (Fig. 2F to I; Table 2).

Sweetpotato characterization. Seven different categories of infected sweetpotato with complete virus genomes were identified (Supplementary Fig. S1): (i) elongated, white-fleshed and whiteskinned tuberous roots, associated with trilobed pointed, purpletinged or purple leaves, and red petioles and stems (two samples); (ii) elongated, orange-fleshed and orange-skinned tuberous roots, associated with heart-shaped purple leaves and green petioles and stems (two samples); (iii) elongated, tuberous roots with whiteand orange-tinged flesh and golden-brown skin, associated with trilobed pointed, purple-tinged green leaves and green petioles and stems (two samples); (iv) elongated, tuberous roots with white- and orange-tinged flesh and golden skin, associated with heart-shaped

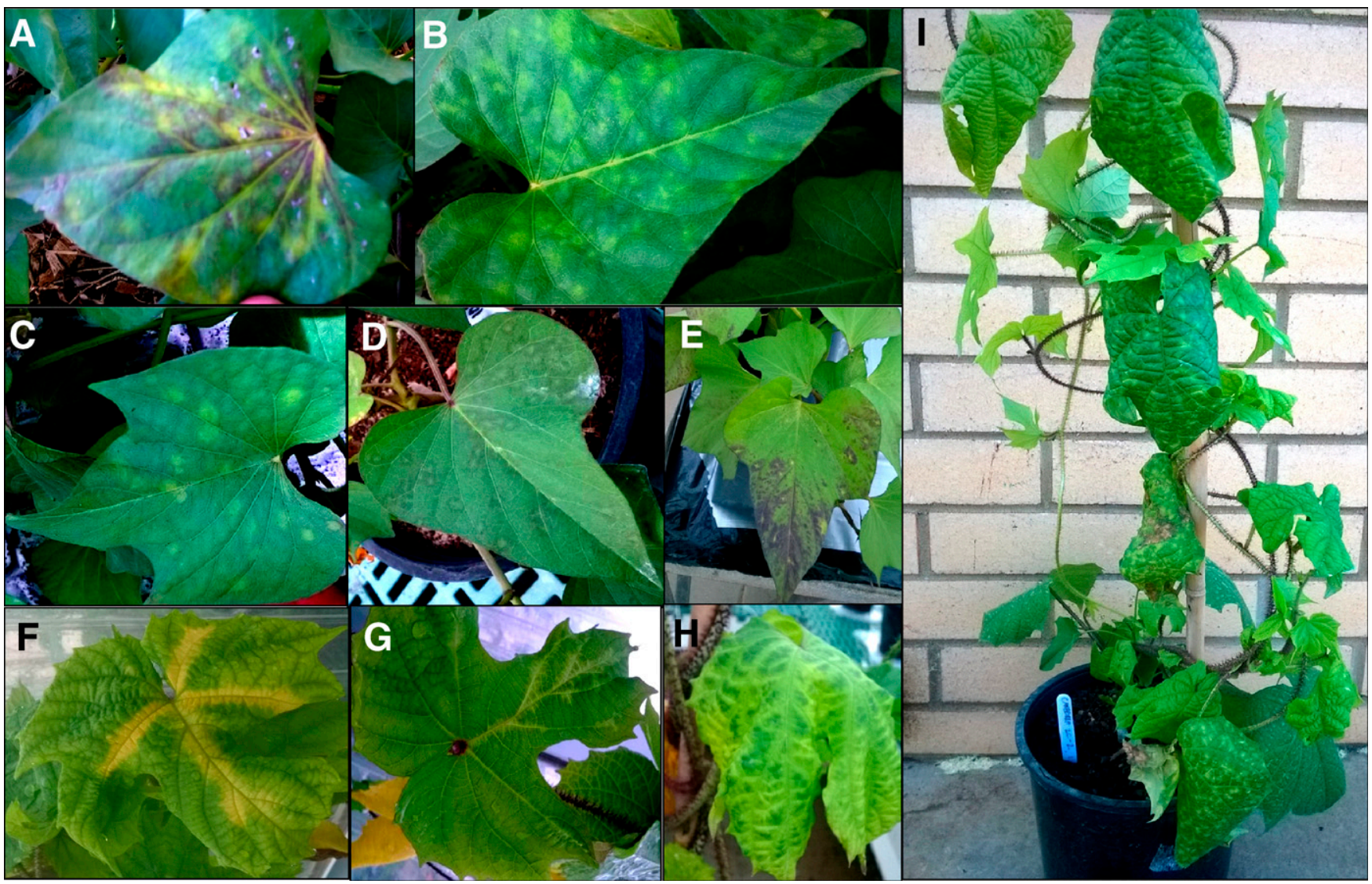

Fig. 2. A, Leaf symptoms of chlorotic blotches and purple rings caused by natural infection with Sweet potato virus $C$ in a sweetpotato plant growing at Broome, northwest Australia in 2015 (sample 1Br-A). Viral leaf symptoms in plants of B to E, sweetpotato, or F to I, graft-inoculated lpomoea setosa growing in the glasshouse: $\mathbf{B}$ and $\mathbf{C}$, chlorotic blotches; $\mathbf{D}$, faint rings; E, purple rings; F, distinct chlorotic vein banding; G, chlorotic vein clearing; H, chlorotic vein banding, mottling, pallor, and malformation; and I, vein clearing, chlorotic blotches, mosaic, and malformation. 
green leaves, and purple-tinged petioles and stems (two samples); (v) oval, tuberous roots with white-cream flesh and red skin, associated with heart shaped, pointed green leaves, and purple-tinged petioles and stems (one sample); (vi) oval- to oblong-shaped tuberous roots with cream flesh and purple skin, associated with heart-shaped purple
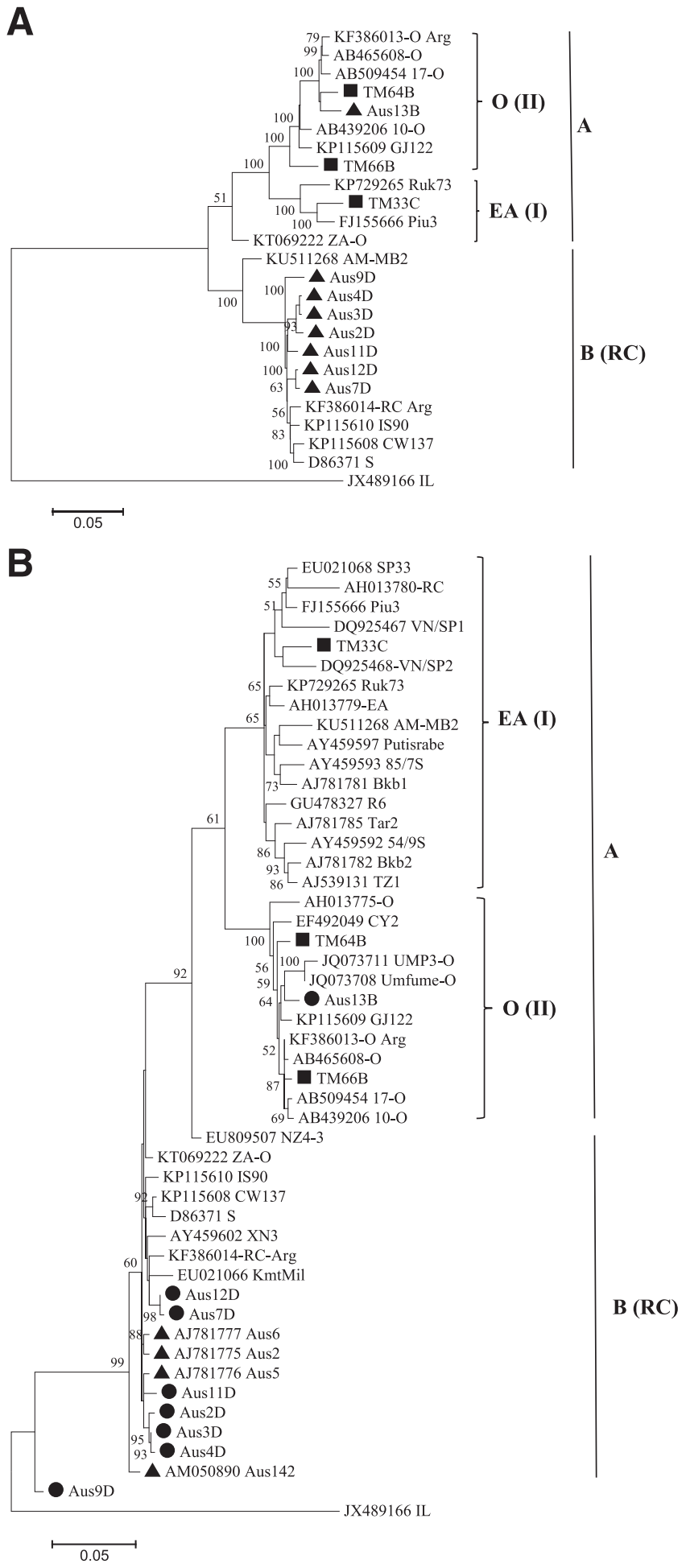

Fig. 3. Maximum-likelihood phylogenetic trees obtained from alignment of nucleotide sequences of Sweet potato feathery mottle virus. Comparisons were made between $\mathbf{A}$, the 11 new genome sequences and 13 genome sequences obtained from GenBank and $B$, the coat protein $(C P)$ genes extracted from the 11 new sequences plus the 4 previous Australian sequences and 33 complete $\mathrm{CP}$ sequences from GenBank. Trees were created in MEGA 7.0.14 using ClustalW with 1,000 replicates. Bootstrap values are percentages, with only values over $50 \%$ shown at the nodes. Trees were rooted with Sweet potato virus C isolate IL (JX489166). Sequence symbols: new Australian $(\bullet)$, previous Australian $(\boldsymbol{\Delta})$, and East Timorese $(\boldsymbol{\bullet})$. leaves, purple-tinged petioles, and green stems (one sample); (vii) elongated, tuberous roots with white-cream flesh and purple skin, associated with heart-shaped or heart-shaped and pointed purple or red leaves, and purple-tinged red or green petioles and stems (three samples). As mentioned above, type 2 was Jewel and type 1 resembled Kestle. Type 7 resembled 'Northern Star,' studied previously (Jones and Dwyer 2007); however, the cultivar identity of the other four types is unclear. No relationship was evident between the type of sweetpotato and which virus was detected (Table 2).

High-throughput sequence data. Analysis of the sweetpotato and I. setosa samples revealed that the numbers of raw paired-end reads obtained from both MiSeq and HiSeq 2500 platforms were $6,260,728$ to $18,282,988$ but, after quality control, these numbers were reduced to 5,405,928 to 18,281,797 (Supplementary Table S2). Following de novo assembly using CLCGW, the numbers of contigs were 757 to 2,743 and the number of reads mapping to the contigs of interest were 85,360 to $3,868,925$. The contigs of interest were more than 10,192 nucleotides (nt) in length, with average coverage of 1,304 to 52,810 . After mapping to reference genomes in Geneious, the lengths of the consensus sequences were 10,456 to $10,809 \mathrm{nt}$, with average coverage of 931 to 50,431 times. The numbers of reads mapped to the reference sequences were 70,139 to $3,770,967$. Final sequence lengths consisted of the consensus of the contig from CLCGW and the consensus from Geneious mapping, and were 10,683 to $11,004 \mathrm{nt}$. All of the sequenced samples had a Q (quality score) 30 of $>98 \%$ and yielded complete genomic sequences. All the contigs of interest were closely related to SPFMV or SPVC. In total, 22 complete polyprotein coding genomes were obtained: 11 each from SPFMV and SPVC. In addition, one partial SPVC sequence and four partial SPFMV sequences (one SPFMV-RC, two SPFMV-O, and one SPFMV-EA) were obtained from three samples (Table 1), and four other sweetpotato viruses from four samples: complete sequences of SPCFV and SPV2 in samples 2a and TM37; Sweet potato virus G (genus Potyvirus, family Potyviridae) in sample TM66; SPV2 in sample 55-6; and a partial sequence of Sweet potato pakakuy virus-strain B (SPPV-B; genus Badnavirus, family Caulimoviridae) in sample Wel-1 (Tables 1 and 2).

Phylogenetic relationships. When the coding regions of the 8 and 3 complete new SPFMV genomes from Australia and East Timor, respectively, were compared with those of 13 SPFMV genomes from other countries, phylogenetic analysis revealed clustering into two major phylogroups, here named A and B (Fig. 3A). Major phylogroup A contained minor phylogroups EA(I) and O(II). Within phylogroup O(II), Australian sequence Aus13B grouped with East Timorese sample TM64B; other sequences present were TM66B from East Timor and five others from Asia and South America. The closest sequences to Aus13B and TM64B were Arg (KF386013) from Argentina, plus 17-O (AB509454) and unknown (AB465608) from Japan. Phylogroup EA(I) included sequences TM33C from East Timor, ZA-O from South Africa, and both Piu3 and Ruk73 from East Africa but none from Australia. Major phylogroup B(RC) consisted of six new Australian sequences and sequences from Europe (one), South America (one), and Asia (three).

When the CP genes from the 11 new SPFMV genomes from East Timor and Australia and 4 other previous Australian CP sequences were compared with 33 others from elsewhere, phylogenetic analysis again revealed major phylogroups A and B (Fig. 3B). Phylogroup A contained minor phylogroups $\mathrm{EA}(\mathrm{I})$ and $\mathrm{O}$ (II) but phylogroup $\mathrm{B}(\mathrm{RC})$ contained none. Minor phylogroup EA(I) contained East Timorese sequence TM33C along with sequences from East Africa countries (12), Vietnam (2), and Peru (2). Minor phylogroup O(II) included Australian sequence Aus13B and East Timorese sequences TM64B and TM66B along with nine sequences from elsewhere. Again, sequences Aus13B from Australia and TM64 from East Timor grouped together. Major phylogroup $\mathrm{B}(\mathrm{RC})$ contained seven new and four old sequences from Australia along with eight other sequences from New Zealand (one), Africa (one), Asia (four), and South America (two).

When the coding regions of the 7 and 4 new complete SPVC genomes from Australia and East Timor, respectively, were compared with 10 genomes from other countries, there were insufficient 
differences to define phylogroups (Fig. 4A). However, the seven Australian sequences and South African sequence ECK17 formed a small, distinct grouping. Also, three East Timorese sequences grouped with seven other sequences from Asia (six) and South America (one). However, East Timorese sequence TM68A grouped separately from the other East Timorese sequences and the Australian sequences, forming a small grouping with sequences AM-MB2 (KU511269) from Peru and C1 (GU207597) from Spain.

When the 11 new SPVC CP nucleotide sequences from Australia and East Timor and 5 previous Australian CP sequences from GenBank were compared with 46 others from elsewhere, phylogenetic analysis revealed the presence of major phylogroups A and B (Fig. 4B). Phylogroup A contained six minor phylogroups (I to VI). Minor phylogroup I contained all 4 new sequences from East Timor (TM33, TM64, TM66, and TM68), and these grouped together with 14 sequences from New Zealand (1), French Polynesia (1), Asia (8), and East Africa (4). Minor phylogroup II contained 3 Australian sequences (Aus1A and Aus2A from Canberra and Aus3A from Broome) which grouped together with 14 sequences from Africa (2), Asia (1), South America (7), North America (2), and Europe (2). Minor phylogroup VI was an Australasian grouping containing two new Australian sequences (Aus5A and Aus10A), five previous Australian sequences (Aus4C, Aus5C, Aus142-AC, Aus55-4C, and Pink-2C) and two New Zealand sequences (NZ4-4 and NZ12). Minor phylogroups III to $\mathrm{V}$ contained sequences from Asia, Africa, and South America but lacked any East Timorese or Australian sequences. Major phylogroup B consisted only of two new Australian sequences from Broome (Aus6A and Aus8A).

Sequence identities. When the 24 complete SPFMV coding regions were examined, the closest genetic match between Australian and East Timorese sequences was the $97.4 \%$ nucleotide identity between Aus13B and TM64 within major phylogroup A's minor phylogroup O(II). The closest genetic match between Australian and non-East Timorese sequences within this phylogroup was the 97.6\% nucleotide identity between Aus13B and Arg (KF386013) from Argentina and unnamed (AB465608) from Japan. The closest genetic match between any East Timorese sequences was the 94.6\% nucleotide identity between TM64B and TM66B, again within phylogroup $\mathrm{O}$ (II). The closest genetic match between Australian sequences in phylogroup $\mathrm{B}(\mathrm{RC})$ was the $99.6 \%$ identity between Aus7D and Aus12D, and the closest genetic match between an Australian sequence and any other sequence was the $98.4 \%$ identity between Aus12D and KF386014 from Argentina. The closest genetic match between an Australian sequence in this phylogroup and the single Australian sequence in phylogroup A was the $86.9 \%$ nucleotide identity between Aus3D and Aus13B.

When the extracted CP genes from the 11 new SPFMV genomes and 4 previous Australian CP sequences were compared with 33 other CP sequences from elsewhere, the closest genetic matches between Australian and East Timorese sequences were the 98.3 and 98.0\% nucleotide identities between Aus13B and TM64B, and Aus13B and TM66B, respectively, both matches occurring within major phylogroup A, minor phylogroup O(II). However, the nucleotide sequence identity between Aus13B and the next closest East Timorese sequence was just $92.4 \%$ with TM33C in minor phylogroup EA(I). Within minor phylogroup O(II), there were close genetic matches (i) between Aus13B and Arg (KF386013) from Argentina plus unnamed (AB465608) from Japan, with 98.7 and 98.5\% nucleotide identities, respectively; and (ii) between Aus13B and South African sequences Umfume-O (JQ073708) and UMP3-O (JQ073711), with 97.9 and 97.1\% nucleotide identities, respectively. The closest genetic matches between a sequence from another part of Southeast Asia and sequences from East Timor and Australia were the 96.5 and $93.8 \%$ nucleotide identities between Vietnamese sequence VN/SP2 (DQ925468) and sequences TM33C and Aus13B, respectively. Within major phylogroup $\mathrm{B}(\mathrm{RC})$, the closest Australian sequence match to outlier Australian sequence Aus9D was the 93.4\% nucleotide identity with Aus2D, and the closest genetic match between an Australian sequence and one from another country was the $98.6 \%$ nucleotide identity between Aus12D and Korean sequence IS90 (KP115610).
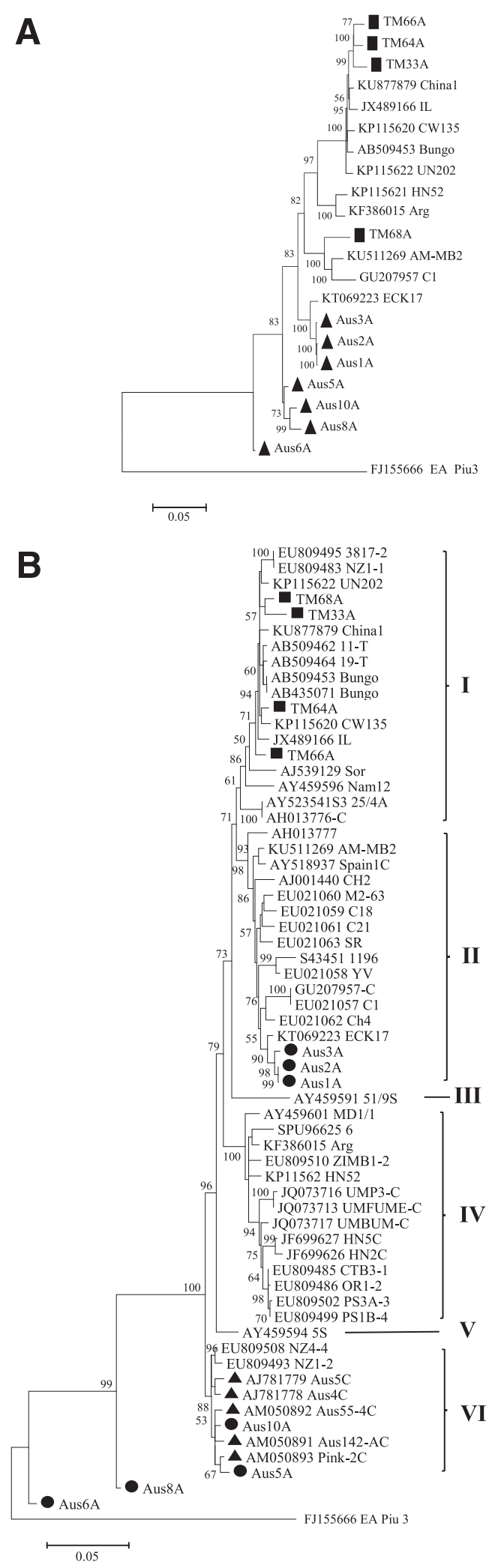

$\mathbf{A}$

Fig. 4. Maximum-likelihood phylogenetic trees obtained from alignment of nucleotide sequences of Sweet potato virus $\mathbf{C}$. Comparisons were made between $\mathbf{A}$, the 11 new genome sequences and 10 genome sequences obtained from GenBank and $\mathbf{B}$, the coat protein (CP) genes extracted from the 11 new sequences plus the 5 previous Australian sequences and the 46 complete $\mathrm{CP}$ sequences from GenBank. Trees were created in MEGA 7.0.14 using ClustalW with 1,000 replicates. Bootstrap values are percentages with values over $50 \%$ shown at the nodes. Trees were rooted with Sweet potato feathery mottle virus-EA isolate Piu 3 (FJ155666). Sequence symbols: new Australian ( $(\bullet)$, previous Australian ( $\mathbf{\Delta})$, and East Timorese $(\boldsymbol{\bullet})$. 
When the 21 complete SPVC coding regions from Australia, East Timor, and elsewhere were analyzed, the closest genetic match between Australian and East Timorese sequences was the $94.1 \%$ nucleotide identity between TM68A and Aus10A. The closest non-Australian sequence match to Aus10A was the $96.1 \%$ nucleotide identity to South African sequence ECK17 (KT069223). The closest match between outlier sequence Aus6A and another sequence was the 96.9\% nucleotide identity with Aus5A. The most distant match between any East Timorese sequences was the $92.8 \%$ nucleotide identity between TM64A and TM68A. The closest genetic match between any Australian sequence and a sequence from elsewhere was the $98.7 \%$ nucleotide identity between Aus3A and South African sequence ECK17 (KT069223). The closest genetic match between any East Timorese sequence and a sequence from elsewhere was 98.2\% nucleotide between TM64A and China1 (KU877879).

When the extracted CP genes from the 11 new SPVC genomes and 5 previous Australian CP sequences were compared with $46 \mathrm{CP}$ sequences from elsewhere, the closest genetic match between Australian and East Timorese sequences was the $96.3 \%$ nucleotide identity between Aus55-4C and TM64A from minor phylogroups VI and I, respectively, within major phylogroup A. The closest match between the three Australian sequences in phylogroup II within major phylogroup A and the four East Timorese sequences in phylogroup I was the $96.2 \%$ nucleotide identity between TM64A and both Aus1A and Aus2A. The closest non-Australian sequence match to Aus55-4C was the $99.0 \%$ nucleotide identity to New Zealand sequence NZ4-4 (EU809508). Within minor phylogroups VI and II, the closest matches between an Australian sequence and sequences from any another country were (i) the 99.1 and $98.8 \%$ nucleotide identities between Aus4C and NZ4-4 and NZ1-2, respectively, both from New Zealand (phylogroup VI); and (ii) the 98.9\% nucleotide identity between Aus3A and South African sequence ECK17 (KT069223) (phylogroup II). The closest genetic match between any East Timorese sequence and a sequence from elsewhere was the $98.7 \%$ nucleotide identity between TM68A and Japanese sequence 11-T (AB509462); however, TM68A also had an 98.3\% nucleotide identity with New Zealand sequence NZ1-1 (EU809495). The closest genetic match between an Australian sequence in minor phylogroup VI and one in another phylogroup was the $95.6 \%$ nucleotide identity between Aus $4 \mathrm{c}$ and Aus3A in minor phylogroup II. Within minor phylogroup I, the closest East Timorese sequence match was the $98.8 \%$ nucleotide identity between TM64A and TM64. Within major phylogroup B, the two Australian sequences it contained, Aus6A and Aus8A, had a nucleotide sequence identity of $94.0 \%$. The least genetic difference between Australian sequences in major phylogroups $\mathrm{A}$ and $\mathrm{B}$ was the $87.3 \%$ nucleotide identity between Aus2A and Aus6A.

\section{Discussion}

This research describes the first complete genome sequences of SPFMV and SPVC from sweetpotato plantings in the Australian continent and the neighboring Southeast Asian country East Timor. Moreover, these new sequences double the complete genomes of each virus available, enabling (i) SPFMV and SPVC phylogenetics to be examined more thoroughly than previously and (ii) deductions about new virus incursions relevant to virus disease quarantine and biosecurity measures. In our SPFMV phylogenetic trees, East Timorese sequences were within major phylogroup A's minor phylogroups $\mathrm{EA}(\mathrm{I})$ or $\mathrm{O}(\mathrm{II})$, whereas Australian sequences were within minor phylogroup O(II) or major phylogroup B(RC). In our SPVC CP tree, East Timorese sequences were all within major phylogroup A's minor phylogroup I, whereas Australian sequences were in major phylogroup A's minor phylogroups II and VI and major phylogroup B. This suggests at least two SPFMV and three SPVC introductions to Australia since agriculture commenced 228 years ago. With SPFMV, evidence of genetic connectivity between Australian and East Timorese sequences was found within major phylogroup A's minor phylogroup $\mathrm{O}(\mathrm{II})$. However, within this same minor phylogroup, there was also a similar genetic match between Australian and single Argentinean and Japanese sequences. With SPVC, no such match between Australian and East Timorese sequences was found but a close match existed between Australian and New Zealand sequences within major phylogroup A's minor 'Australasian' phylogroup VI. Movement of sweetpotato tuberous roots between countries through vegetative propagation before postentry quarantine testing was introduced seems the most likely way that SPFMV and SPVC reached Australia. However, the hypothesis that important plant viral pathogens of economically important crops are arriving in tropical northern Australia by crossing the sea separating it from its northern neighbors could not be discounted for SPFMV. Despite the low quality of RNA extracted from sweetpotato leaves blotted onto FTA cards, TruSeq-stranded library preparation using Ribo-Zero depletion chemistry with suitable modifications to FTA card libraries still allowed new SPFMV and SPVC genome sequences to be obtained by Illumina sequencing. Several different types of symptoms developed in SPFMV- and SPVC-infected sweetpotato and graft-inoculated I. setosa plants resembling symptoms recorded previously in these hosts, including in sweetpotato plants growing under field conditions in northern Australia. Also, use of tuberous root and foliage descriptors readily identified seven distinct types of sweetpotato among the collected samples that SPFMV or SPVC came from. This research has implications regarding healthy sweetpotato pathogen stock programs and entry of damaging viral pathogens into northern Australia.

With SPVC, an important outcome was the delineation of two major phylogroups, A and B, with A being subdivided into six minor phylogroups (I to VI). SPFMV subdivided into two major phylogroups, $\mathrm{A}$ and $\mathrm{B}(\mathrm{RC})$, with A containing minor phylogroups $\mathrm{EA}(\mathrm{I})$ and $\mathrm{O}(\mathrm{II})$; however, sequence numbers were insufficient for subdivision of $\mathrm{B}(\mathrm{RC})$. This SPFMV phylogeny resembles its previous subdivision into three phylogroups (EA, O, and RC) (Kreuze et al. 2000; Tairo et al. 2005). In complete genome or $\mathrm{CP}$ trees, sequences from South American and Asian sequences were present within most minor SPFMV and SPVC phylogroups. Occurrence of South American sequences in these phylogroups is consistent with both viruses having originated in the Americas, where sweetpotato was first domesticated. The closest genetic match between any Australian and East Timorese SPFMV sequences was the 97.4\% (genome) and $98.3 \%$ (CP) nucleotide identity between two sequences within phylogroup A-O(II) but there was also a $97.6 \%$ (genome) and 98.7\% (CP) match between an Australian and an Argentinian sequence within this phylogroup. The closest genetic match between an Australian and any other SPFMV sequence was the $98.6 \% \mathrm{CP}$ nucleotide identity between Australian and Korean sequences within phylogroup $\mathrm{B}(\mathrm{RC})$. Although these findings suggest that SPFMV and SPVC entered Australia via infected tuberous roots, because of the single Australian SPFMV sequence in phylogroup A-O(II) they do not preclude its possible introduction by windborne vector aphids from East Timor. This is despite it having come from a tuberous root purchased in a market in southern Australia because the harvested crop could still have come from northern Australia. Alternatively, importation of infected tuberous roots into both Australia and East Timor might have occurred from the same external source, or the tuberous roots might even have been exported from Australia to East Timor. Judging by the numbers of Australian CP sequences present within different phylogroups, their larger numbers in SPFMV $\mathrm{B}(\mathrm{RC})$ and SPVC A-VI suggest that these isolates might have arrived first, whereas the few in SPFMV A-O(II) and SPVC A-1 suggest that these isolates might have arrived more recently. Alternatively, the large numbers of isolates within phylogroups SPFMV B(RC) and SPVC (A-VI) and smaller numbers in SPFMV A-O(II) and SPVC A-1 could be because (i) the former are better adapted than the latter and, hence, able to increase their populations faster, regardless of arriving earlier or later; or (ii) the former are more widely dispersed globally and, therefore, multiple introductions might have occurred with them. Future availability of more complete SPVC and SPFMV genomes would offer better understanding of the global distribution of their different phylogroups, allow more accurate confirmation of their origins, and help trace their evolution. 
The name "EA" for SPFMV phylogroup A-EA(I) is an abbreviation for East Africa, where this phylogroup's distribution was originally considered restricted, leading to the hypothesis that East Africa might constitute a subcenter for diversity in its evolution (Tairo et al. 2005; Tugume et al. 2010). However, this phylogroup now contains additional sequences (mostly $\mathrm{CP}$ ) from elsewhere: for example, southern Africa (e.g., Zambia and Madagascar), Southeast Asia (Vietnam and East Timor), and the sweetpotato crop's American domestication center (Peru). This suggests that EA members most likely first evolved in the Americas before being distributed via infected tuberous roots to Africa and other continents. We predict that, due to increasing human movement and world trade in plants and plant products, including sweetpotato (Jones 2009), it is only a matter of time before members of this phylogroup are found in more world regions. In addition, the " $\mathrm{RC}$ " phylogroup $(=\mathrm{B}[\mathrm{RC}])$, which was originally named after the russet crack tuberous root symptom, now contains isolates not associated with this syndrome, as observed in our study. With these two SPFMV phylogroups, lack of congruity between geographically or biologically based names and the properties of the isolates within each of them demonstrates the need for neutral within-species nomenclature. Jones and Kehoe (2016) proposed use of Latinized numerals to avoid misleading names and ambiguities arising from within-species phylogroup nomenclature derived from biological properties or geography. The proposed naming system avoided serious consequences for virus research, disease management, or international trade arising from incorrect assumptions made when phylogroups have names that incorrectly identify group member properties. It allows for the isolates within each phylogroup to be considered without preconceived notions based on such names. Letters of the alphabet and Latinized numbers provide a suitable neutral alternative for major and minor phylogroup nomenclature, respectively. Using this approach, SPFMV EA became A-I, O (= ordinary) became A-II, and RC became B.

Directly blotting sweetpotato leaves onto FTA cards resulted in RNA extracts with low RNA Integrity Numbers. With suitable modifications to FTA card libraries, TruSeq-stranded library preparation using Ribo-Zero depletion chemistry for plant rRNA allowed new SPFMV and SPVC genome sequences to be obtained. Actinomycin $\mathrm{D}$ in the first-strand synthesis mix allowed RNA-dependent synthesis, thereby improving cDNA strand fidelity and reducing any chimera formation causing false virus detections and bioinformatics challenges, especially with coinfections. Adenylation of the $3^{\prime}$ end provided complimentary overhangs, also minimizing chimera formation (Guerret et al. 2017; Haas et al. 2013; Levin et al. 2010; Maina et al. 2016a,b,c,d,e,f; Stranneheim et al. 2011). PE (paired end) strand-specific sequencing with long reads improved genome assembly (Haas et al. 2013). Moreover, finding SPPV-B provided another example of the RNA-seq procedure successfully detecting a DNA virus in sweetpotato (Kashif et al. 2012; Kreuze et al. 2005, 2008, 2009; Maina et al. 2017e). In the future, combining RNA-seq strand-specific with TruSeq Nano DNA libraries would likely permit more robust detection of different DNA or RNA sweetpotato viruses. Furthermore, Gu et al. (2014) found that analysis of fibrous and immature tuberous root samples by high-throughput sequencing resulted in higher expression levels of sweetpotato virus transcripts than leaf sample analysis. Possibly, extracts from fibrous or immature tuberous root samples might provide an alternative means to optimize virus detection of RNA and DNA viruses from sweetpotato.

Mixed infections between SPFMV and Sweet potato chlorotic stunt virus (SPCSV; genus Crinivirus, family Closteroviridae) elicit sweet potato virus disease (SPVD), the most destructive sweetpotato virus syndrome globally (Karyeija et al. 2000; Kokkinos and Clark 2006; Tairo et al. 2005; Untiveros et al. 2007). Fortunately for Australia and East Timor, SPCSV has not yet been found in either country. Also, although infection with SPFMV and SPVC can cause mild foliage symptoms in sweetpotato plants growing in the field in northern Australia (Tairo et al. 2006a) (this study), the only severe sweetpotato disease found thus far that elicits similar yield losses to SPVD is "Little Leaf Disease" caused by sweet potato little leaf phytoplasma (Tairo et al. 2006b); however, this rarely reaches sufficient crop incidences to elicit major yield losses. In this study, several virus symptoms developed in infected sweetpotato and graft-inoculated I. setosa plants, and several of the symptoms found in infected sweetpotato plants growing in the glasshouse were also observed under field conditions. Also, I. setosa developed more severe symptoms than sweetpotato plants, as found previously (Tairo et al. 2006a). Our sweetpotato descriptor approach resembles that used previously for revealing diversity among lines and solving duplication of germplasm entries (Huaman 1991). Use of tuberous root characteristics as primary descriptors and foliage characteristics as secondary descriptors identified seven different types but no relationship was evident between these types and whether SPFMV, SPVC, or both were detected. The descriptor diversity revealed may reflect natural mutations for traits based on tuberous root flesh or skin color and leaf or vine characteristics arising from vegetative propagation via shoot cuttings or adventitious buds taken from tuberous roots (Gichuru et al. 2006; Karuri et al. 2009; Villordon and LaBonte 1996).

The widespread occurrence of SPFMV and SPVC in Australian sweetpotato found in this and previous studies (Jones and Dwyer 2007; Tairo et. al. 2005, 2006a) suggests the need to include more rigorous, routine virus testing in the national sweetpotato pathogentested stock program. This program is based on heat, meristem culture, and chemical treatments to eliminate infection from sweetpotato plants followed by graft inoculation of shoot samples from the treated plants to I. setosa, observing grafted plants for symptoms and only propagating further from sweetpotato plants from which grafted scions fail to induce symptoms in I. setosa (QLD-GOV 2015). However, virus infection is sometimes symptomless in I. setosa (Gu et al. 2014); therefore, testing of samples by molecular techniques that detect multiple viruses simultaneously (e.g., quantitative real-time RT-PCR assays) (Mortimer-Jones et al. 2009) would not only help avoid DNA and RNA virus infections being missed but also reveal new infections occurring in early stages of field propagation. Moreover, as global climate change progresses, more extreme weather events are predicted for northern Australia. This includes more intense tropical cyclones originating in Southeast Asia and annual monsoonal winds that blow from Australia's northern neighbors (Jones 2009, 2016; Jones and Barbetti 2012). Such alterations in weather conditions would increase the likelihood of winged insect vectors reaching the continent and introducing SPCSV and other sweetpotato viruses. Quarantine measures over importation of plants and plant products, and Australia's geographic remoteness, have enabled it to remain free from SPVD and many of the world's other more severe crop virus diseases. The expected increase in insect vector arrivals from Southeast Asia arising from more intense and frequent cyclones and wind currents suggests the need to increase viral pathogen surveillance activities in crops growing in northern Australia. Such increased surveillance, followed by rapid action to contain or eradicate new virus incursions, would help avoid establishment of damaging viruses such as SPCSV, or of virulent strains of already established viruses, currently damaging sweetpotato and other crops elsewhere in the world.

\section{Acknowledgments}

This study forms part of a Ph.D. project by S. Maina at the University of Western Australia (UWA). UWA and the Department of Agriculture and Food Western Australia (DAFWA) both provided glasshouse and laboratory facilities for this research. We thank E. Gajda, M. Banovic, F. Wangari, R. Creasy, and B. Piasini for glasshouse support at DAFWA and UWA; B. Coutts for providing sweetpotato sample Wel-1; and M. You of the School of Agriculture and Environment, UWA for administrative support. Approval for sampling in East Timor was obtained from the Plant Quarantine Department of the National Directorate of Quarantine and Biosecurity, Ministry of Agriculture and Fisheries, Dili. Permission to import plant material blotted on the FTA cards was obtained from the Australian Federal Department of Agriculture, who granted permit number IP15004160.

\section{Literature Cited}

Altschul, S. F., Gish, W., Miller, W., Myers, E. W., and Lipman, D. J. 1990. Basic local alignment search tool. J. Mol. Biol. 215:403-410.

Atkey, P. T., and Brunt, A. A. 1987. Electron microscopy of an isometric Caulimolike virus from sweet potato (Ipomoea batatas). J. Phytopathol. 118:370-376. 
Bao, Y., Chetvernin, V., and Tatusova, T. 2014. Improvements to pairwise sequence comparison (PASC): A genome-based web tool for virus classification. Arch. Virol. 159:3293-3304.

Brunt, A. A. 1987. Surveys for Plant Viruses and Virus Diseases in the Solomon Islands. Report of the Food and Agriculture Organisation of the United Nations (FAO). FAO, Rome.

CABI/EPPO. 2003. Sweet potato feathery mottle virus. Distribution Maps of Plant Diseases, No. 892. CAB International, Wallingford, UK.

Clark, C. A., Davis, J. A., Abad, J. A., Cuellar, W. J., Fuentes, S., Kreuze, J. F., Gibson, R. W., Mukasa, S. B., Tugume, A. K., Tairo, F. D., and Valkonen, J. P. 2012. Sweetpotato viruses: 15 years of progress on understanding and managing complex diseases. Plant Dis. 96:168-185.

Coleman, E. A., Hughes, M. J., Jackson, G. V., Komolong, B., and Guaf, E. 2009. Genetics and disease as factors in the yield decline of sweetpotato in the Papua New Guinea highlands. Pages 33-42 in: Soil Fertility in Sweetpotato Based Cropping Systems in the Highlands of Papua New Guinea. Australian Centre for International Agricultural Research, Canberra, ACT Australia.

Colinet, D., Nguyen, M., Kummert, J., Lepoivre, P., and Xia, F. Z. 1998. Differentiation among potyviruses infecting sweet potato based on genus and virus-specific reverse transcription polymerase chain reaction. Plant Dis. 82:223-229.

Coutts, B. A., Kehoe, M. A., Webster, C. G., Wylie, S. J., and Jones, R. A. C. 2011. Zucchini yellow mosaic virus: Biological properties, detection procedures and comparison of coat protein gene sequences. Arch. Virol. 156:2119-2131.

Denham, T., Haberle, S., and Lentfer, C. 2004. New evidence and revised interpretations of early agriculture in highland New Guinea. Antiquity 78:839-857.

Eagles, D., Walker, P. J., Zalucki, M. P., and Durr, P. A. 2013. Modelling spatiotemporal patterns of long-distance Culicoides dispersal into northern Australia. Prev. Vet. Med. 110:312-322.

EPPO. 2014. Plant Quarantine Database. Online publication. European and Mediterranean Plant Protection Organization, Paris. http://www.eppo.int/ DATABASES/pqr/pqr.htm

FAOSTAT. 2015. Food and Agriculture Organization Statistical Databases. The Food and Agriculture Organization of the United Nations, Rome.

Fletcher, J. D., Lewthwaite, S. L., Fletcher, P. J., and Dannock, J. 2000. Sweet potato (kumara) virus disease surveys in New Zealand. Pages $42-47$ in: Int. Workshop Sweetpotato Cultivar Decline Study. National Agricultural Research Center for Kyushu Okinawa Region, Miyajakonojo, Japan.

Gibb, K. S., and Padovan, A. C. 1993. Detection of sweet potato feathery mottle virus in sweet potato grown in Northern Australia using an efficient and simple assay. Int. J. Pest Manage. 39:223-228.

Gibbs, A. J., Mackenzie, A., Wei, K., and Gibbs, M. J. 2008. The potyviruses of Australia. Arch. Virol. 153:1411-1420.

Gibbs, A. J., and Mackenzie, A. M. 1997. A primer pair for amplifying part of the genome of all potyvirids by RT-PCR. J. Virol. Methods 63:9-16.

Gichuru, V., Aritua, G. W., Lubega, R., Edema, E., Adipula, E., and Rubaihayo, P. R. 2006. A preliminary analysis of diversity among East African sweet potato landraces using morphological and simple sequence repeats (SSR) markers. Acta Hortic. 703:159-164

Gu, Y. H., Tao, X., Lai, X. J., Wang, H. Y., and Zhang, Y. Z. 2014. Exploring the polyadenylated RNA virome of sweet potato through high-throughput sequencing. PLoS One 9:e98884.

Guerret, M. G. L., Nyalugwe, E. P., Maina, S., Barbetti, M. J., van Leur, J. A. G., and Jones, R. A. C. 2017. Biological and molecular properties of a Turnip mosaic virus (TuMV) strain that breaks TuMV resistances in Brassica napus. Plant Dis. 101:674-683.

Ha, C., Revill, P., Harding, R. M., Vu, M., and Dale, J. L. 2008. Identification and sequence analysis of potyviruses infecting crops in Vietnam. Arch. Virol. 153: $45-60$

Haas, B. J., Papanicolaou, A., Yassour, M., Grabherr, M., Blood, P. D., Bowden, J., Couger, M. B., Eccles, D., Li, B., Lieber, M., MacManes, M. D., Ott, M., Orvis, J., Pochet, N., Strozzi, F., Weeks, N., Westerman, R., William, T., Dewey, C. N., Henschel, R., LeDuc, R. D., Friedman, N., and Regev, A. 2013. De novo transcript sequence reconstruction from RNA-seq using the Trinity platform for reference generation and analysis. Nat. Protoc. 8: 1494-1512.

Huaman, Z., ed. 1991. Descriptors for Sweet Potato. International Board for Plant Genetic Resources, FAO, Rome.

Hutterer, K. P. 1983. The natural and cultural history of Southeast Asian agriculture: Ecological and evolutionary considerations. Anthropos 78:169-212.

IsHak, J. A., Kreuze, J. F., Johansson, A., Mukasa, S. B., Tairo, F., Abo El-Abbas, F. M., and Valkonen, J. P. T. 2003. Some molecular characteristics of three viruses from SPVD affected sweet potato plants in Egypt. Arch. Virol. 148: 2449-2460.

Jones, R. A. C. 2009. Plant virus emergence and evolution: Origins, new encounter scenarios, factors driving emergence, effects of changing world conditions, and prospects for control. Virus Res. 141:113-130.

Jones, R. A. C. 2016. Future scenarios for plant virus pathogens as climate change progresses. Adv. Virus Res. 95:87-147.

Jones, R. A. C., and Barbetti, M. J. 2012. Influence of climate change on plant disease infections and epidemics caused by viruses and bacteria. CAB Rev. 7:1-32.

Jones, R. A. C., and Dwyer, D. I. 2007. Detection of Sweet potato chlorotic fleck virus and Sweet potato feathery mottle virus-strain O in Australia. Australas. Plant Pathol. 36:591-594.
Jones, R. A. C., and Kehoe, M. A. 2016. A proposal to rationalize within-species plant virus nomenclature: Benefits and implications of inaction. Arch. Virol. 161:2051-2057.

Karuri, H. W., Ateka, E. M., Amata, R., Nyende, A. B., and Muigai, A. W. T. 2009 Morphological markers cannot reliably identify and classify sweetpotato genotypes based on resistance to sweet potato virus disease and dry matter content. J. Appl. Biosci. 15:820-828.

Karyeija, R. F., Gibson, R. W., and Valkonen, J. P. T. 1998. The significance of Sweetpotato feathery mottle virus in subsistence sweetpotato production in Africa. Plant Dis. 82:4-15.

Karyeija, R. F., Kreuze, J. F., Gibson, R. W., and Valkonen, J. P. T. 2000. Synergistic interactions of a potyvirus and a phloem-limited crinivirus in sweet potato plants. Virology 269:26-36

Kashif, M., Pietilä, S., Artola, K., Jones, R. A. C., Tugume, A. K., Mäkinen, V., and Valkonen, J. P. T. 2012. Detection of viruses in sweetpotato from Honduras and Guatemala augmented by deep-sequencing of small-RNAs. Plant Dis. 96:1430-1437.

Katoh, K., Misawa, K., Kuma, K.-I., and Miyata, T. 2002. MAFFT: A novel method for rapid multiple sequence alignment based on fast Fourier transform. Nucleic Acids Res. 30:3059-3066.

Kays, S., Wang, Y., and McLaurin, W. 2005. Chemical and geographical assessment of the sweetness of the cultivated sweet potato clones of the world. J. Am. Soc. Hortic. Sci. 130:591-597.

Kearse, M., Moir, R., Wilson, A., Stones-Havas, S., Cheung, M., Sturrock, S., Buxton, S., Cooper, A., Markowitz, S., Duran, C., Thierer, T., Ashton, B., Meintjes, P., and Drummond, A. 2012. Geneious basic: An integrated and extendable desktop software platform for the organization and analysis of sequence data. Bioinformatics 12:1647-1649.

Kehoe, M. A., Coutts, B. A., Buirchell, B., and Jones, R. A. C. 2014. Plant virology and next generation sequencing: Experiences with a Potyvirus. PLoS One 9: e104580.

Kokkinos, C. D., and Clark, C. A. 2006. Interactions among Sweet potato chlorotic stunt virus and different potyviruses and Potyvirus strains infecting sweetpotato in the United States. Plant Dis. 90:1347-1352.

Kreuze, J. F., Karyeija, R. F., Gibson, R. W., and Valkonen, J. P. T. 2000 Comparisons of coat protein gene sequences show that East Africa isolates of Sweet potato feathery mottle virus form a genetically distinct group. Arch. Virol. 145:567-574.

Kreuze, J. F., Klein, I. S., Lazaro, M. U., Chuquiyuri, W. J. C., Morgan, G. L. Mejía, P. G. C., Ghislain, M., and Valkonen, J. P. T. 2008. RNA silencingmediated resistance to a Crinivirus (Closteroviridae) in cultivated sweetpotato (Ipomoea batatas L.) and development of sweetpotato virus disease following co-infection with a Potyvirus. Mol. Plant Pathol. 9:589-598.

Kreuze, J. F., Perez, A., Untiveros, M., Quispe, D., Fuentes, S., Barker, I., and Simon, R. 2009. Complete viral genome sequence and discovery of novel viruses by deep sequencing of small RNAs: A generic method for diagnosis, discovery and sequencing of viruses. Virology 388:1-7.

Kreuze, J. F., Savenkov, E. I., Cuellar, W., Li, X., and Valkonen, J. P. T. 2005. Viral Class 1 RNase III involved in suppression of RNA silencing. J. Virol. 79:7227-7238.

Kumar, S., Stecher, G., and Tamura, K. 2016. MEGA7: Molecular evolutionary genetics analysis version 7.0 for bigger datasets. Mol. Biol. Evol. 33:1870-1874

Levin, J. Z., Yassour, M., Adiconis, X., Nusbaum, C., Thompson, D. A., Friedman, N., Gnirke, A., and Regev, A. 2010. Comprehensive comparative analysis of strand-specific RNA sequencing methods. Nat. Methods 7:709-715.

Loebenstein, G., Thottappilly, G., Fuentes, S., and Cohen, J. 2009. Virus and phytoplasma diseases. Pages 105-134 in: The Sweetpotato. G. Loebenstein and G. Thottappilly, eds. Springer, Dordrecht, The Netherlands.

Maina, S., Coutts, B. A., Edwards, O. R., de Almeida, L., Kehoe, M. A., Ximenes, A., and Jones, R. A. C. 2017a. Zucchini yellow mosaic virus populations from East Timorese and northern Australian cucurbit crops: Molecular properties, genetic connectivity and biosecurity implications. Plant Dis. 101:1236-1245.

Maina, S., Coutts, B. A., Edwards, O. R., de Almeida, L., Ximenes, A., and Jones, R. A. C. 2017b. Papaya ringspot virus populations from East Timorese and northern Australian cucurbit crops: Biological and molecular properties, and absence of genetic connectivity. Plant Dis. 101:985-993.

Maina, S., Edwards, O. R., Barbetti, M. J., de Almeida, L., Ximenes, A., and Jones, R. A. C. 2016a. Deep sequencing reveals complete genome of Sweet potato virus $G$ from East Timor. Genome Announc. 4:e00957-16.

Maina, S., Edwards, O. R., de Almeida, L., Ximenes, A., and Jones, R. A. C 2016b. Complete genome sequences of the Carlavirus Sweet potato chlorotic fleck virus from East Timor and Australia. Genome Announc. 4:e00414-16.

Maina, S., Edwards, O. R., de Almeida, L., Ximenes, A., and Jones, R. A. C. 2016c. Complete genome sequences of the Potyvirus Sweet potato virus 2 from East Timor and Australia. Genome Announc. 4:e00504-16.

Maina, S., Edwards, O. R., de Almeida, L., Ximenes, A., and Jones, R. A. C. 2016d. First complete genome sequence of Suakwa aphid-borne yellows virus from East Timor. Genome Announc. 4:e00718-16.

Maina, S., Edwards, O. R., de Almeida, L., Ximenes, A., and Jones, R. A. C 2016e. First complete genome sequence of Bean common mosaic necrosis virus from East Timor. Genome Announc. 4:e01049-16.

Maina, S., Edwards, O. R., de Almeida, L., Ximenes, A., and Jones, R. A. C 2017c. Metagenomic analysis of cucumber RNA from East Timor reveals an Aphid lethal paralysis virus genome. Genome Announc. 5:e01445-16. 
Maina, S., Edwards, O. R., de Almeida, L., Ximenes, A., and Jones, R. A. C. 2017d. RNA-seq strand specific library from East Timorese cucumber sample reveals complete Cucurbit aphid-borne yellows virus genome. Genome Announc. 5:e0320-17.

Maina, S., Edwards, O. R., de Almeida, L., Ximenes, A., and Jones, R. A. C. 2017e. First complete Squash leaf curl China virus genomic segment DNA-A sequence from East Timor. Genome Announc. 5:e0483-17.

Maina, S., Edwards, O. R., and Jones, R. A. C. 2017f. Two complete genome sequences of Squash mosaic virus from 20-year-old cucurbit leaf samples from Australia. Genome Announc. 5:e00778-17.

Maina, S., Edwards, R., and Jones, R. A. C. 2016f. First complete genome sequence of Pepper vein yellows virus from Australia. Genome Announc. 4: e00450-16.

Mortimer-Jones, S. M., Jones, M. G. K., Jones, R. A. C., Thomson, G., and Dwyer, G. I. 2009. A single tube, quantitative real-time RT-PCR assay that detects four potato viruses simultaneously. J. Virol. Methods 161:289-296.

Moyer, J. W., Cali, B. B., Kennedy, G. G., and Abu-Ghadir, M. F. 1980. Identification of sweet potato feathery mottle virus strains in North Carolina. Plant Dis. 64:762-764.

Moyer, J. W., and Salazar, L. F. 1989. Viruses and virus like diseases of sweet potato. Plant Dis. 73:451-455.

Mukasa, S. B., Tairo, F., Kullaya, A., Rubaihayo, P. R., and Valkonen, J. P. T. 2003. Coat protein sequence analysis reveals occurrence of new strains of Sweet potato feathery mottle virus in Uganda and Tanzania. Virus Genes 27: 49-56.

Ndunguru, J., Taylor, N. J., Yadav, J., Aly, H., Legg, J. P., Aveling, T., Thompson, G., and Fauquet, C. M. 2005. Application of FTA technology for sampling, recovery and molecular characterization of viral pathogens and virus-derived transgenes from plant tissues. Virol. J. 2:45.

Pearson, M. N., and Grisoni, M. 2002. Records of plant viruses for the Pacific Islands. Australas. Plant Pathol. 31:15-26.

Prain, G., Machmud, M., and Rusmadi. 1998. Evaluation of virus diseases. Annual subproject progress report 080304 for Indonesia. International Potato Center, Lima, Peru.

Purnomo, B. W. 2003. Sweet potato feathery mottle virus (SPFMV) elimination of four sweet potato local superior varieties of Papua origin by using meristem culture. Indonesian. J. Agron. 31:81-88.

QLD-GOV. 2015. Producing Pathogen-tested Sweetpotato Planting Material. Online publication. Department of Agriculture and Fisheries, Queensland Government, Brisbane, QLD Australia. https://www.daf.qld.gov.au/plants/ fruit-and-vegetables/vegetables/sweetpotato/pathogen-tested-planting-material
Rännäli, M., Czekaj, V., Jones, R. A. C., Fletcher, J. D., Mu, L., Davis, R. I., and Valkonen, J. P. T. 2009. Molecular characterization of Sweet potato feathery mottle virus (SPFMV) isolates from Easter Island, French Polynesia, New Zealand and southern Africa. Plant Dis. 93:933-939.

Ryu, K. H., Kim, S. J., and Park, W. M. 1998. Nucleotide sequence analysis of the coat protein genes of two Korean isolates of sweet potato feathery mottle potyvirus. Arch. Virol. 143:557-562.

Salazar, L. F., and Fuentes, S. 2000. Current knowledge on major virus diseases of sweet potatoes. Pages 14-19 in: Int. Workshop Sweetpotato Cultivar Decline Study. National Agricultural Research Center, Kyushu, Okinawa Region, Miyajakonojo, Japan.

Stranneheim, H., Werne, B., Sherwood, E., and Lundeberg, J. 2011. Scalable transcriptome preparation for massive parallel sequencing. PLoS One 6:e21910.

Tairo, F., Jones, R. A. C., and Valkonen, J. P. T. 2006a. Potyvirus complexes in sweetpotato: Occurrence in Australia, serological and molecular resolution, and analysis of the Sweet potato virus 2 (SPV2) component. Plant Dis. 90:1120-1128.

Tairo, F., Jones, R. A. C., and Valkonen, J. P. T. 2006b. Phytoplasma from little leaf disease affected sweetpotato in Western Australia: Detection and phylogeny. Ann. Appl. Biol. 149:9-14.

Tairo, F., Mukasa, S. B., Jones, R. A. C., Kullaya, A., Rubaihayo, P. R., and Valkonen, J. P. T. 2005. Unravelling the genetic diversity of the three main viruses involved in sweet potato virus disease (SPVD) and its practical implications. Mol. Plant Pathol. 6:199-211.

Tugume, A. K., Cuéllar, W. J., Mukasa, S. B., and Valkonen, J. P. T. 2010. Molecular genetic analysis of virus isolates from wild and cultivated plants demonstrates that East Africa is a hotspot for the evolution and diversification of sweet potato feathery mottle virus. Mol. Ecol. 19:3139-3156.

Untiveros, M., Fuentes, S., and Kreuze, J. 2008. Molecular variability of Sweet potato feathery mottle virus and other potyviruses infecting sweet potato in Peru. Arch. Virol. 153:473-483.

Untiveros, M., Fuentes, S., and Salazar, L. F. 2007. Synergistic interaction of Sweet potato chlorotic stunt virus (Crinivirus) with carla-, cucumo-, ipomo-, and potyviruses infecting sweet potato. Plant Dis. 91:669-676.

Valverde, R. A., Clark, C. A., and Valkonen, J. P. T. 2007. Viruses and virus disease complexes of sweet potato. Plant Viruses 1:116-126.

Villordon, A. Q., and LaBonte, D. R. 1996. Genetic variation among sweet potatoes propagated through nodal and adventitious sprouts. J. Am. Hortic. Sci. 121:170-174.

Webster, C. G. 2008. Characterisation of Hardenbergia mosaic virus and development of microarrays for detecting viruses in plants. Ph.D. thesis, Murdoch University. 